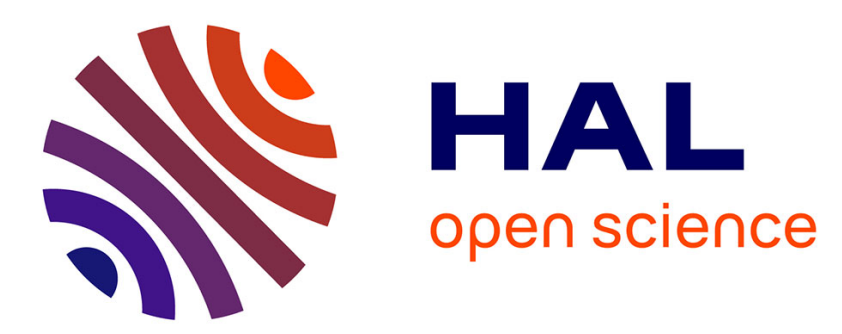

\title{
A study of genetic variability in Sesbania pachycarpa DC. in Burkina Faso
}

Yacoubou Bakasso, Jean-Didier Zongo

\section{To cite this version:}

Yacoubou Bakasso, Jean-Didier Zongo. A study of genetic variability in Sesbania pachycarpa DC. in Burkina Faso. Agronomie, 2000, 20 (4), pp.431-438. 10.1051/agro:2000139 . hal-00886041

\section{HAL Id: hal-00886041 \\ https://hal.science/hal-00886041}

Submitted on 1 Jan 2000

HAL is a multi-disciplinary open access archive for the deposit and dissemination of scientific research documents, whether they are published or not. The documents may come from teaching and research institutions in France or abroad, or from public or private research centers.
L'archive ouverte pluridisciplinaire HAL, est destinée au dépôt et à la diffusion de documents scientifiques de niveau recherche, publiés ou non, émanant des établissements d'enseignement et de recherche français ou étrangers, des laboratoires publics ou privés. 


\title{
Original article
}

\section{A study of genetic variability in Sesbania pachycarpa DC. in Burkina Faso}

\author{
Yacoubou BAKASSO ${ }^{\text {a* }}$, Jean-Didier ZONGO ${ }^{\mathrm{b}}$ \\ ${ }^{a}$ Université AM de Niamey, Faculté des Sciences, Département de Biologie, BP 10662, Niamey, Niger \\ ${ }^{\mathrm{b}}$ Genetic Laboratory, FAST, Ouagadougou University, BP 7021, Ouagadougou 03, Burkina Faso
}

(Received 20 July 1999; accepted 31 January 2000)

\begin{abstract}
A sample of 42 ecotypes of Sesbania pachycarpa were collected in Burkina Faso. The ecotypes were evaluated for 6 agronomic traits (height, branch number, diameter, pod number, seed weight, 100-seed weight). The study demonstrated considerable variability among the ecotypes. Multivariate analysis separated the samples into 4 groups based on the following discriminating characters: plant height, pod number and branch number. This variability, which is essentially genetic, shows considerable potential for improvement of the species.
\end{abstract}

\section{Sesbania pachycarpa DC. / evaluation / genetic variability / Burkina Faso}

Résumé - Une étude de la variabilité génétique de Sesbania pachycarpa DC. au Burkina Faso. À la suite d'une prospection à l'intérieur du Burkina Faso, un échantillon de 42 écotypes de Sesbania pachycarpa a été collecté. Ces écotypes ont été observés dans un dispositif en blocs sur une même station expérimentale pour évaluer 6 caractères agromorphologiques sur la plante (hauteur de la plante, diamètre de la tige principale à maturité, nombre de ramifications, nombre de gousses, poids de 100 graines, poids de graines). Cette étude a permis de mettre en évidence l'existence d'une variabilité pour tous les caractères étudiés au sein de cet échantillon. L'analyse multivariée répartit les écotypes en 4 groupes, avec comme caractères discriminants le nombre de gousses, la hauteur et le nombre de ramifications de la plante. Cette variabilité, essentiellement génétique, permettra d'entreprendre l'amélioration de l'espèce.

Sesbania pachycarpa DC. / évaluation / variabilité génétique / Burkina Faso

Communicated by Mervyn Humphreys (Aberystwyth, UK)

* Correspondence and reprints

bakasso@yahoo.com 


\section{Introduction}

Sesbania pachycarpa DC. is a leguminous species which thrives during the rainy season at the roadside and along damp ditches in African countries [2]. It belongs to the genus Sesbania, which comprises about 60 species divided into the following subgenera: Agati, Daubentonia and Sesbania [7]. Thirty-two species of the Sesbania subgenus have been identified in Africa, of which two-thirds are annual plants (Gillet, 1963; cited in [7]).

Species of the Sesbania genus have several uses, including human nutrition: the leaves, flowers, pods and seeds are used in various dishes in Asia [8], and in Senegal, S. rostrata leaves are also consumed by humans [5]. Nevertheless, these plants are mainly used to improve soil fertility as their symbiotic association with Rhizobium permits them to fix atmospheric nitrogen $(\mathrm{N})$. They can fix up to $600 \mathrm{~kg} \mathrm{~N} \cdot \mathrm{ha} \cdot \mathrm{yr}$ (Onim, 1987; cited in [10]) and can have a $\mathrm{N}$ content of up to $53.8 \mathrm{~g} \mathrm{~N} \cdot \mathrm{kg}$ dry matter (DM) in their aerial parts [1]. S. pachycarpa leaves are used as fodder, and also to treat wounds against guinea worm [2]. The dry seeds eliminate the guinea worm as well as its eggs [3]. They also contain an oil whose triglyceride composition is the same as that of soybean oil [1].

Thus the Sesbania genus has much potential, and merits further investigation. This study was undertaken on $S$. pachycarpa, which is the most widespread species in Burkina Faso, but also the least studied. In fact, it appears that very few researchers have been interested in this species, and relevant literature is practically non-existent. As variability is the basis of genetic improvement in all species, the aim of this work was to study the variability in S. pachycarpa through an evaluation of a sample of ecotypes from 3 geographic zones of Burkina Faso.

\section{Materials and methods}

Forty two ecotypes collected in 3 agroclimatic zones of Burkina Faso were studied (Fig. 1). These

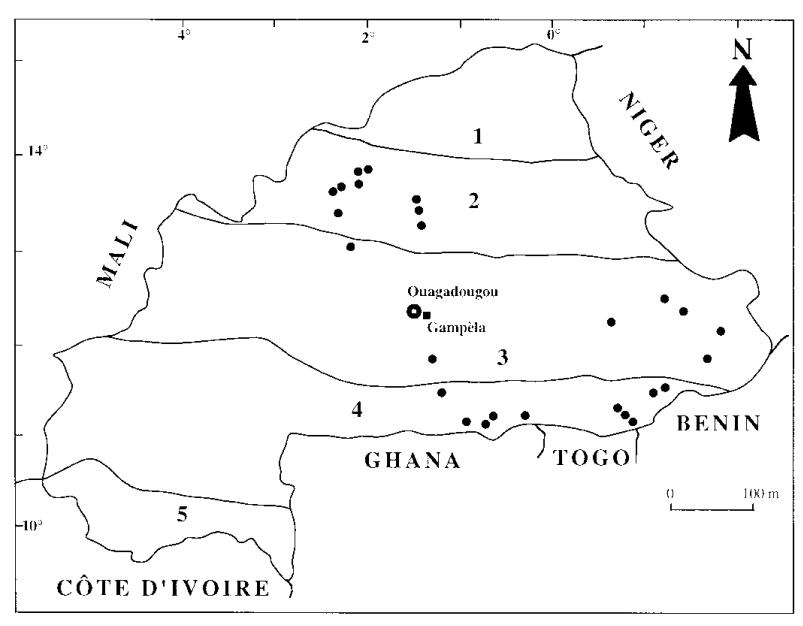

Figure 1. Sites of origin of Sesbania pachycarpa ecotypes. Collection site $(\bullet)$, Sahelian climate zone (1), sub-Sahelian climate zone (2), north-Sudanese climate zone (3), southSudanese climate zone (4), and sub-Sudanese climate zone (5).

ecotypes were observed during the 1992 rainy season at the Gampèla experimental station located $20 \mathrm{~km}$ east of Ouagadougou (Fig. 1). The ecotypes were grown in a randomized, complete-block design with 3 replications. In each block, an ecotype was represented by a row $8 \mathrm{~m}$ long, in which 5 mounds were positioned every $2 \mathrm{~m}$. Successive rows were $3 \mathrm{~m}$ apart and the blocks were situated 4 $\mathrm{m}$ apart. Three to four seeds were sown on each mound. Ten days after germination, the plants were thinned to 1 plant per mound.

Plant development was examined from germination to maturity (corresponding to $75 \%$ of the pods yellowing per plant on $50 \%$ of the plants per ecotype). The traits studied were plant height at maturity (PHM), the number of branches per plant at maturity $(\mathrm{NbB})$, the basal diameter of the principal stem at maturity (Dia), number of days to $50 \%$ flowering (DFl), number of days to $50 \%$ maturity (DMat), number of pods per plant (NbP), the 100seed weight (HSW) and the total seed weight per plant (SW). In this study, we were only interested in those traits associated with $\mathrm{N}$ production, mainly the aerial biomass (PHM, NbB and Dia); those associated with oil production (PNb, HSW and $\mathrm{SW}$ ), and those reflecting the rate of plant development (DFl and DMat). 
Table I. Mean performance of 42 ecotypes of Sesbania pachycarpa.

\begin{tabular}{|c|c|c|c|c|c|c|}
\hline Variable & Minimum & Maximum & Mean & SD & $\mathrm{CV}$ & $F$ \\
\hline PHM (cm) & 189.33 & 315.22 & 226.63 & 27.83 & 12.28 & $* *$ \\
\hline Dia $\quad(\mathrm{cm})$ & 1.55 & 3.35 & 2.32 & 0.47 & 20.18 & $* *$ \\
\hline $\mathrm{NbB}$ & 4.33 & 40.22 & 16.76 & 9.83 & 58.65 & $* *$ \\
\hline $\mathrm{DFl} \quad(\mathrm{j})$ & 50.33 & 87.33 & 64.46 & 11.22 & 17.41 & $* *$ \\
\hline DMat（j) & 92.00 & 135.00 & 107.74 & 13.34 & 12.39 & $* *$ \\
\hline $\mathrm{NbP}$ & 122.40 & 386.00 & 237.40 & 66.90 & 28.10 & $* *$ \\
\hline SW $\quad(g)$ & 66.55 & 186.22 & 127.78 & 34.33 & 26.87 & ns \\
\hline HSW (g) & 1.84 & 2.68 & 2.37 & 0.17 & 7.44 & $* *$ \\
\hline
\end{tabular}

PHM: plant height at maturity; Dia: basal diameter of the principal stem at maturity; NbB: number of branches/plant at maturity; DFl: number of days to 50\% flowering; DMat: number of days to 50\% maturity; NbP: number of pods/plant; SW: total seed weight/plant; HSW: 100 -seed weight/plant; SD: standard deviation; CV: coefficient of variation; $F: F$-test; **significance at the $1 \%$ level of probability; ns: non significant.

Data processing was carried out using STATITCF software (OITCF 2-86492-123-5, October 1991) for variance (ANOVA) and multivariate (MANOVA) analysis. This included variance analysis of the traits studied, factor analysis of the relationships between traits, ascending and hierarchical classification of ecotypes into groups and discriminant analysis to characterize groups formed from ascending hierarchical classification.

\section{Results}

\subsection{Analysis of ecotype performance}

A wide range of expression as well as high coefficients of variation were observed for all the traits studied (Tab. I). The shortest plant measured $189.3 \mathrm{~cm}$, whereas the tallest measured $315.2 \mathrm{~cm}$, i.e., a range of $125.9 \mathrm{~cm}$ and a coefficient of variation of 12.2. The earliest plant flowered more than 1 month before the latest. The best performing plant produced 3 times more pods (386) than the worst performing plant (122). For branch number, the highest branch number was 10 times more than the lowest.

A large standard deviation was observed for branch number (58.65), pod number (28.09), seed weight (26.86) and diameter (20.18). The ecotypes differed significantly for all the traits studied except for seed weight per plant (Tab. I).

\subsection{Analysis of relationships between traits}

The correlation matrix between the 8 traits studied showed 2 groups of significant correlations (Tab. II). There were positive correlations between the traits associated with $\mathrm{N}$ production (PHM, Dia and $\mathrm{NbB}$ ) and which were correlated to developmental cycles (DFl and DMat). For the traits associated with oil production, $\mathrm{NbP}$ was positively correlated to SW (0.83), whereas the correlation between $\mathrm{NbP}$ and $\mathrm{HSW}$ was negative $(-0.44)$.

Factor analysis confirmed the different correlations observed between the traits (Fig. 2). The graphical representation of axes 1 and 2, which accounted for $82.4 \%$ of the total variability, shows a good distribution of ecotypes and variables. The first axis (58.9\% of the total variation) contrasts ecotypes with good vegetative development and

Table II. Correlation matrix between the variables.

\begin{tabular}{|c|c|c|c|c|c|c|}
\hline Variable & PHM & Dia & $\mathrm{NbB}$ & DFl DMat & $\mathrm{NbP}$ & SW \\
\hline Dia & $0.49 * *$ & & & & & \\
\hline $\mathrm{NbB}$ & $0.37 * *$ & $* 0.85 * *$ & & & & \\
\hline $\mathrm{DFl}$ & 0.03 & $0.77 * *$ & $0.74 * *$ & & & \\
\hline DMat & 0.08 & $0.79 * *$ & $0.78^{* *}$ & $0.98 * *$ & & \\
\hline $\mathrm{NbP}$ & 0.30 & $0.45 * *$ & 0.20 & $0.15 \quad 0.11$ & & \\
\hline SW & 0.26 & $0.37 *$ & 0.06 & $0.03-0.03$ & $0.83 * *$ & \\
\hline HSW - & -0.28 & -0.12 & 0.04 & $0.02-0.00$ & $-0.44 * *$ & -0.117 \\
\hline
\end{tabular}

Abbreviations as in Table I. *significance at the $1 \%$ level of probability; **significance at the $1 \%$ level of probability. 


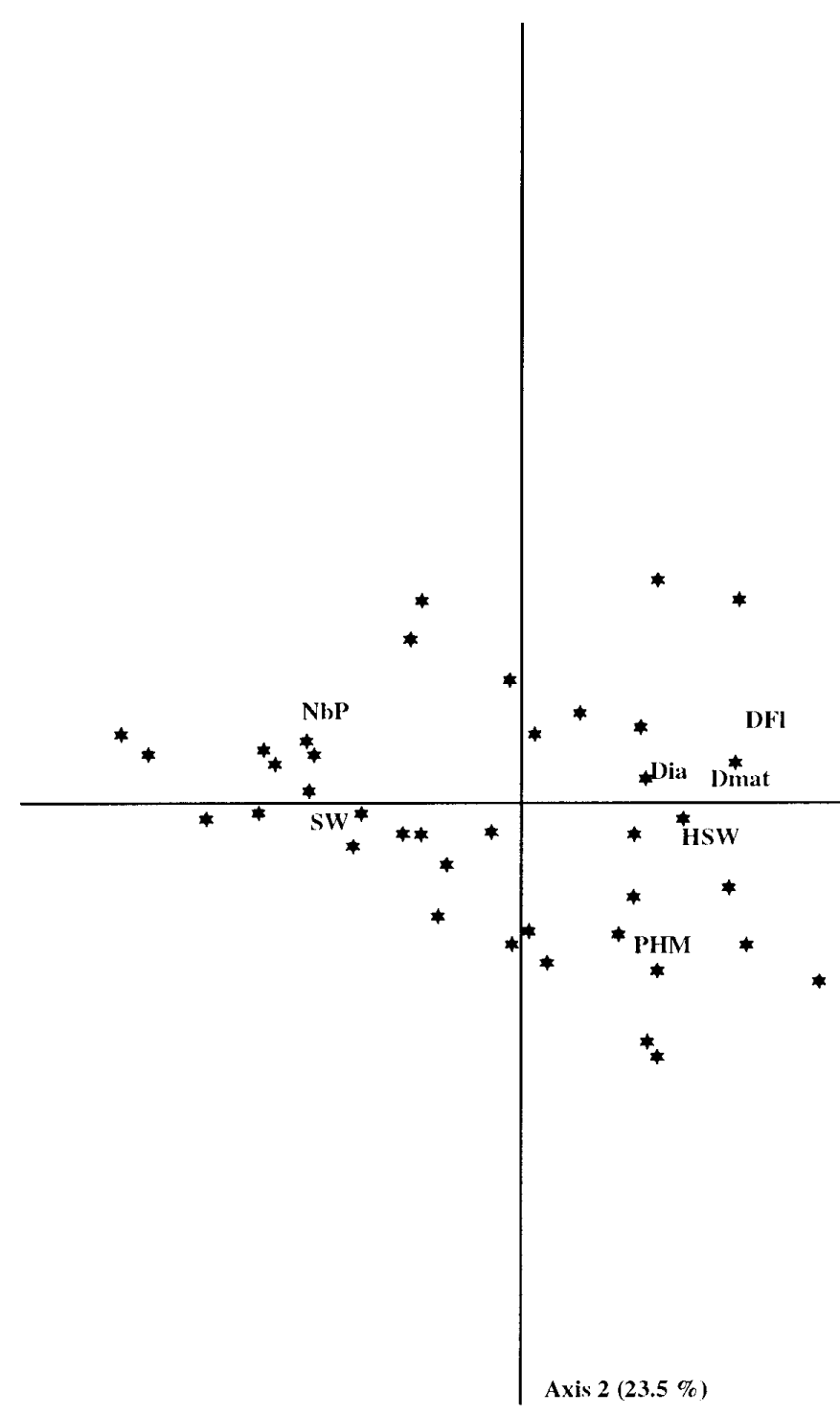

$\mathrm{NbB}$ Axis $1(58.9 \%)$ late flowering with ecotypes having the best pod and seed yield. The second axis, accounting for only $23.5 \%$ of the total variation, characterizes the ecotypes with a large number of branches.

\subsection{Analysis of population structure}

\subsubsection{Ecotype groupings}

The ascending hierarchical classification based on the different traits, with aggregation criteria based on the weighted average of Euclidian dis-
Figure 2. Ecotype $(\star)$ and variable representation on the halfplane $(82.4 \%)$ of the factorial analysis of correspondence; PHM: plant height at maturity, Dia: basal diameter of the principal stem at maturity; NbB: number of branches/plant at maturity; Dfl: days to $50 \%$ flowering; DMat: days to $50 \%$ maturity; NbP: number of pods/plant; SW: seed weight/plant; HSW: 100-seed weight/plant.

tances, gave the cluster tree shown in Figure 3. Truncation at a level of 90.78 resulted in 4 groups: group I comprised ecotypes 1, 2, 4, 7, 10, 26, 28, 30, 31, 32 and 42; group II comprised ecotypes 3, $5,6,8,9,12,13,15,16,24,25,27,36,37,39$ and 41; group III comprised ecotypes $11,14,17,18$, $19,20,21,22,23,29,34,35$ and 38 ; group IV comprised 2 ecotypes: 33 and 40.

The average performances showed that they were identical for 100-seed weight (Tab. III). The variables, basal diameter of principal stem at maturity and 100 -seed weight did not contribute to node 


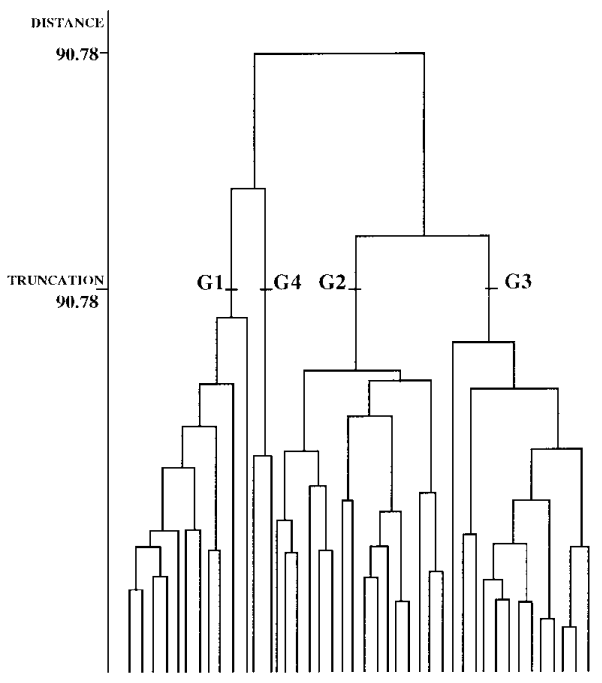

Figure 3. Dendrogram of the 42 ecotypes of $S$. pachycarpa from Burkina Faso based on Euclidian distance.

Table III. Mean performance of groups determined by ascending hierarchical classification.

\begin{tabular}{|c|c|c|c|c|}
\hline \multirow[t]{2}{*}{ Variable } & \multicolumn{4}{|c|}{ Group } \\
\hline & $\begin{array}{c}\mathrm{I} \\
(n=11)\end{array}$ & $\begin{array}{c}\text { II } \\
(n=16)\end{array}$ & $\begin{array}{c}\text { III } \\
(n=13)\end{array}$ & $\begin{array}{c}\text { IV } \\
(n=2)\end{array}$ \\
\hline PHM (cm) & 227.4 & 229.0 & 210.5 & 308.4 \\
\hline Dia $\quad(\mathrm{cm})$ & 2.5 & 2.3 & 2.0 & 3.2 \\
\hline $\mathrm{NbB}$ & 17.3 & 16.3 & 13.5 & 38.2 \\
\hline $\mathrm{DFl} \quad$ (j) & 65.9 & 64.3 & 62.3 & 71.7 \\
\hline DMat (j) & 108.6 & 107.3 & 106.0 & 117.8 \\
\hline $\mathrm{NbP}$ & 323.3 & 235.6 & 161.7 & 270.6 \\
\hline SW $\quad(g)$ & 166.6 & 129.8 & 89.3 & 148.4 \\
\hline HSW (g) & 2.3 & 2.4 & 2.4 & 2.4 \\
\hline
\end{tabular}

Abbreviations as in Table I.

formation, i.e., a partition level of the ecotypes (Tab. IV).

The first division of ecotypes was made on the basis of pod number, seed weight and plant height (Tab. IV). Two sets were identified: one was composed of ecotypes performing well with regard to pods, seeds and maturity; the other set comprised lower-performing ecotypes.

The first set division was based on height (64\%), pod number $(27 \%)$, branch number $(4 \%)$ and seed
Table IV. Variable contribution to the nodes (level of partition).

\begin{tabular}{lrrrrrr}
\hline \multirow{2}{*}{ Node } & \multicolumn{7}{c}{ Variable } \\
& PHM & NbB & DFl & DMat & NbP & SW \\
\hline N \# 83 & 2 & 0 & 0 & 0 & 80 & 17 \\
N \# 82 & 64 & 4 & 0 & 1 & 27 & 3 \\
N \# 81 & 4 & 0 & 0 & 0 & 74 & 21 \\
N \# 80 & 15 & 0 & 1 & 1 & 79 & 3 \\
N \# 79 & 8 & 6 & 13 & 20 & 52 & 2 \\
N \# 78 & 5 & 0 & 2 & 1 & 91 & 0 \\
N \# 77 & 2 & 2 & 3 & 7 & 0 & 86 \\
N \# 76 & 7 & 24 & 19 & 29 & 12 & 9 \\
N \# 75 & 91 & 0 & 0 & 0 & 2 & 7 \\
N \# 74 & 51 & 7 & 11 & 17 & 0 & 14 \\
N \# 73 & 21 & 12 & 24 & 35 & 8 & 1 \\
N \# 72 & 27 & 0 & 0 & 0 & 42 & 30 \\
N \# 71 & 21 & 0 & 17 & 18 & 42 & 2 \\
N \# 70 & 8 & 1 & 3 & 8 & 37 & 43 \\
\hline
\end{tabular}

Abbreviations as in Table I. HSW: 100-seed weight/plant not contributed to the node (partition level).

weight (3\%). This division differentiated 2 ecotypes on the basis of their height and large branch number. They constituted group IV, and the other ecotypes of the first set constituted group I.

The second set division was based on branch number $(73 \%)$, seed weight $(22 \%)$, and height $(5 \%)$. It led to the subdivision of this set into groups II and III, which differed distinctly in their production of pods and seeds.

\subsubsection{Group characterization}

The discriminating factor analysis gave a combined variable $F$-test for each axis - denoted pseudo- $F$. This analysis gave a pseudo- $F$ value of 119.58 with an associated probability of $<0.0001$ for the first axis, and included a significant $F$-value of 80.12 for pod number (Tab. V). Thus, the groups differed from one another with the average characteristics displayed in Table V.

The ANOVA indicated significant differences between the groups for the PHM, Dia, NbB, NbP and SW traits. With $95.2 \%$ of the ecotypes included, the groups obtained were representative of the total variability. 


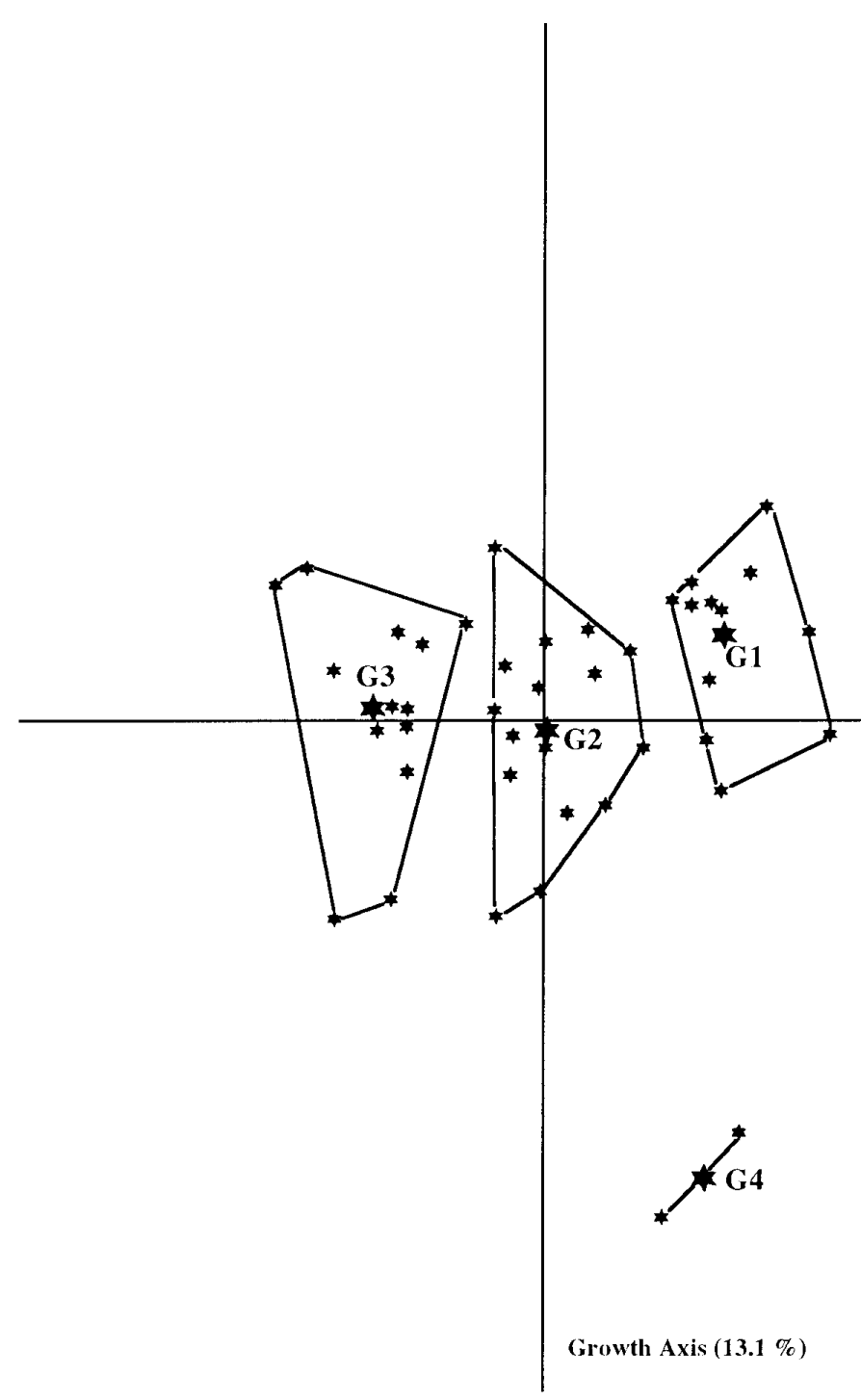

The first axis (Fig. 4), which accounts for $86.6 \%$ of the total variation, is closely correlated to $\mathrm{NbP}$, HSW and SW and may be considered as a productivity axis. The second axis, which accounts for only $13.1 \%$ of the total variation, is closely correlated with $\mathrm{PHM}$ and $\mathrm{NbB}$. It characterizes ecotypes with good vegetative development and may be considered as a growth axis.

The position of the groups on the half-plane formed by these 2 axes (99.7\% of the variation) characterizes them as follows:
Figure 4. The ecotype discriminating factorial analysis $(\star)$ and gravity centres $(\star)$ of the groups represented on the half-plane (99.7\% of the total variation).

- group I comprises ecotypes with a high pod productivity combined with an average vegetative development and very good pod and seed production. These plants originate mostly from the north Sudanese zone, and others from the sub-Sahelian zone. These zones are characterized by a relatively short rainy season. The plants of group I grew well during the experiment, even though the 1992 rainy season was particularly short; group II comprised plants of average performance for all the traits studied. The ecotypes in this group were of diverse 
Table V. Total variation for axes, correlation between variables and discriminating axes and centre of gravity values for groups on discriminating axes.

\begin{tabular}{|c|c|c|c|c|}
\hline & Axis 1 & Axis 2 & Axis 3 & \\
\hline Variation (\%) & 86.6 & 13.1 & 0.2 & \\
\hline Pseudo- $F$ & 119.58 & 18.10 & 0.34 & \\
\hline Variable & & & & $F$ \\
\hline PHM & 0.5479 & -0.8366 & -0.0136 & $14.39 * *$ \\
\hline Dia & 0.8389 & -0.5407 & 0.0655 & $7.53 * *$ \\
\hline $\mathrm{NbB}$ & 0.5195 & -0.8418 & 0.1473 & $4.63 * *$ \\
\hline $\mathrm{DFl}$ & 0.8181 & -0.5631 & 0.1183 & $0.48 \mathrm{~ns}$ \\
\hline DMat & 0.6221 & -0.7534 & 0.2138 & $0.46 \mathrm{~ns}$ \\
\hline $\mathrm{NbP}$ & 0.9899 & 0.1401 & 0.0168 & $80.12 * *$ \\
\hline SW & 0.9950 & 0.0840 & -0.0541 & $40.02 * *$ \\
\hline HSW & -0.9773 & -0.2111 & 0.0134 & $1.37 \mathrm{~ns}$ \\
\hline Group I & 1.2283 & 0.6056 & 0.1180 & \\
\hline Group II & 0.0076 & -0.0874 & -0.2067 & \\
\hline Group III & -1.2125 & 0.0871 & 0.1253 & \\
\hline Group IV & 1.0647 & -3.1980 & 0.1903 & \\
\hline
\end{tabular}

Abbreviations as in Table I. **significance at the $1 \%$ level of probability; ns: non significant.

origin and from different zones; group III comprised plants with poor pod and seed production, associated with poor yield and small height. They are early ecotypes, exclusively from the subSahelian zone of the extreme north-west of Burkina Faso. They are adapted to a short rainy season; group IV comprised late plants which combined height with an average pod and seed production. The plants of this group have a very good vegetative development, a large diameter and are well ramified. They originated from the extreme south of the south-Sudanese zone. Originating from a zone with a long rainy season (6-7 months according to Guinko [9]), the ecotypes of group IV showed a long period of vegetative development and were in full fruit when the rain stopped, which explains their low yield.

\section{Discussion}

The ANOVA and MANOVA carried out on 8 agro-morphologic characters demonstrated the existence of inter- and intra-ecotype variability. In fact, the ecotypes demonstrated a very large variation for a range of traits which is essentially genetic, as these traits are expressed in standard experimental conditions. Cherifi et al. [4] have drawn the same conclusion for 2 species of Medicago. The characters NbP, PHM and NbR were the most discriminating variables, which allowed division of the ecotypes into 4 groups. For this species, variable correlation is essential in discriminating ecotypes because the analysis of individual variables would not be of general interest.

The wide range of genetic variability observed is supported by the cleistogamic reproduction mode of these species. Autogamy favours inter-plant homogeneity within populations, but promotes diversity between ecotypes which may increase within an area of adaptation and explain the large ecological amplitude of the Sesbania genus [7].

The observed variability for PHM, Dia, NbB, $\mathrm{NbP}$, HSW and WS traits enhances the possibility of genetic improvement of this species for agronomic and industrial use. S. pachycarpa could be a plant with good future use, either as green manure or as an oleaginous plant. However, for better exploitation of the species, a systematic evaluation of the protein and oil composition will be necessary. In fact, even if the quality of the oil extracted from its seeds is undeniable, its poor tenor $(5.58 \%$ according to Bakasso [1]) limits its economic interest. A toxicological study of S. pachycarpa oil will undoubtedly provide useful information regarding its value.

\section{References}

[1] Bakasso Y., Contribution à l'étude des potentialités de Sesbania pachycarpa DC. (Fabaceae) et de ses potentialités d'amélioration génétique, thèse de doctorat $3^{\text {e }}$ cycle, sciences biologiques appliquées, Univ. de Ouagadougou, 1996, p. 112.

[2] Bérhaut J., Flore illustrée du Sénégal, Vol. V, Government of Senegal, 1976, pp. 505-520. 
[3] César de la Pradilla F., Plantes médicinales vendues sur les marchés de Ouagadougou, 5th ed., 1992, p. 130.

[4] Cherifi K., Boussaid M., Marrakchi M., Diversité génétique de quelques populations naturelles de Medicago ciliaris (L.) Krock et de Medicago intertexta (L.) Mill. I. Analyse de la variabilité morphologique, Agronomie 13 (1993) 895-908.

[5] CTA, Engrais : se mettre au vert, Spore $n^{\circ} 12$, Bull. Bimestriel, Centre technique de coopération agricole et rurale, 1988, pp. 1-3.

[6] CTA, Les promesses de Sesbania rostrata pour employer moins d'engrais, Spore $\mathrm{n}^{\circ} 14$, Bull. Bimestriel, Centre technique de coopération agricole et rurale, 1988, pp. 8, 9.
[7] Evans D.O., What is Sesbania? Botany, taxonomy, plant geography and natural history of the perennial members of the genus, in: Macklin B., Evans D.O. (Eds.), Perennial Sesbania Species in Agroforestry Systems, ICRAF-NFTA, pp. 5-13.

[8] Ferantinos L., Human consumption of Sesbania grandiflora in perennial Sesbania species in agroforestry systems, ICRAF-NFTA, 1990, p. 105.

[9] Guinko S., Végétation de la Haute Volta, thèse de Doctorat d'État es Sciences Naturelles, Univ. Bordeaux III, 1984, p. 397.

[10] Onim J.F.M., Otieno K., Dzowela B., The role of Sesbania as multipurpose trees in small scale farms in western Kenya, in: Macklin B., Evans D.O. (Eds.), Perennial Sesbania: Species in Agroforestry Systems, ICRAF-NFTA; 1990, pp. 167-179. 